\title{
SIMULTANEOUS CONTAMINATION OF TRANSFUSION BLOOD WITH ENTEROBACTER AGGLOMERANS AND PSEUDOMONAS FLUORESCENS, SUPPOSEDLY FROM THE PILOT TUBES
}

\author{
M. Felsby*, G. Munk-ANDERSEn $\dagger$, AND K. Siboni $\ddagger$ \\ The Middelfart Hospital*, DK 5500, and the Blood Bankt and the State Serum \\ Institute Regional Laboratory $\ddagger$, Odense University Hospital, DK 5000, Denmark
}

BACTERIAL contamination of donor blood is the nightmare of the blood bank. This contamination may come from many sources, including the bottle, the transfusion set, disinfectant fluids, hand lotions and utensils. Episodes in which contaminated bank blood caused disease-sometimes fatal-in the transfused patients were described repeatedly in the 1940s and early 1950s (see, for example, Borden and Hall, 1951; Braude et al., 1952). One serious episode occurred in Copenhagen in 1958 (Kristensen, 1960), in which the contaminant was Pseudomonas fluorescens, type 63 (Jessen, 1965).

The pilot tubes should also be sterile, because bacterial growth may hamper compatibility tests; nevertheless bacteria have sometimes been grown from these tubes, e.g., Enterobacter liquefaciens (Lautrop, 1972) and Aeromonas hydrophila (Siboni, 1972).

We report the investigation of two incidents in which transfusion of blood contaminated with $E$. agglomerans, group G1 (Ewing and Fife, 1971) and P. fluorescens, type 54 (Jessen) was followed by a febrile reaction, and in which we concluded that the source of infection was the pilot tubes.

\section{BACTERIOLOGICAL METHODS}

Blood from transfusion bottles $(0.5 \mathrm{ml})$ was inoculated into each of four tubes of serum broth, eight tubes of semi-solid agar, and four tubes of thioglycollate agar; $0.15 \mathrm{ml}$ was also sown on to a blood-agar plate. Other fluids were examined in a similar way. When Gramnegative rods were found, they were counted by plating ten-fold dilutions on ConradiDrigalski agar. Swabs were seeded on to blood-agar plates and Conradi-Drigalski agar plates. The inoculated media were left at room temperature $\left(21^{\circ}-23^{\circ} \mathrm{C}\right)$ except for four tubes of semi-solid agar which were kept at $4^{\circ} \mathrm{C}$.

The ability of organisms to grow at different temperatures was examined as follows. An overnight broth culture was diluted ten-fold from $10^{1}$ to $10^{10}$. From each of the dilutions $10^{5}$ to $10^{10}, 0 \cdot 1-\mathrm{ml}$ volumes were sown into tubes of semi-solid agar, five tubes per dilution. The tubes were read for turbidity on each of the subsequent 24 days, and the results were used to calculate, for each day at each temperature, an ID50 per $0.1 \mathrm{ml}$ of the original culture, i.e., an estimate of the dilution of culture from which turbidity had developed on the day in question. This is based on Lwoff's ideas (see Lwoff, 1969), as adapted by Olsen (1966), and is analogous to Benyesh-Melnick and Melnick's (1959) method of studying the rct $/ 40^{\circ}$ Poliovirus marker.

Other media were as described by Lautrop (1956) or by Hugh and Leifson (1953).

\section{RESULTS}

\section{Investigation of the incidents}

On 2 May 1972 we received the remainder of a bottle of blood that had been administered intravenously to a patient who subsequently had a febrile reaction but recovered, and from it we grew the two organisms, E. agglomerans $\left(4 \times 10^{8}\right.$ per $\left.\mathrm{ml}\right)$ and $P$. fluorescens $\left(6 \times 10^{5}\right.$ per $\mathrm{ml}$ ). The blood had come from the bank of a provincial hospital and had been collected

Received 29 Nov. 1972; accepted 18 Feb. 1973.

J. MED. MICROBIOL.-vol. 6 (1973) 
on 13 Apr. 1972. When the results of the culture were known, it was decided to stop the use of blood from this bank and to supply the hospital from the nearest university hospital.

The blood bank. Some 1400 donors were bled each year in a room $(3.25 \mathrm{~m} \times 15.5 \mathrm{~m})$ on the ground floor of the hospital. The donors' skin was disinfected with propyl alcohol, and the tube-cannula sets had been sterilised by ionising radiation. Blood was collected into autoclaved $500-\mathrm{ml}$ bottles each containing acid-citrate-dextrose solution (citrate solution: U.S.P. formula A); the rubber membrane was disinfected with propyl alcohol before being perforated and again after the cannula was withdrawn. The blood left in the plastic tube was allowed to run into a sterile pilot tube containing the same citrate solution and this was then fixed to the neck of the bottle.

Bacteriological investigations in the blood bank on 9 May 1972 revealed the following. Of 39 bottles of blood, no growth was obtained from 38 and E. agglomerans ( $10^{9}$ per $\mathrm{ml}$ ) and $P$. fluorescens $\left(2 \times 10^{7}\right.$ per $\left.\mathrm{ml}\right)$ were isolated from the remaining bottle. There was no bacterial growth from eight unused blood bottles, from the hand lotion, the soap and soapdish, a solution of benzalkonium chloride and the propyl alcohol. A few colonies of organisms other than those found in the blood appeared in a culture of paper cloth and one of two cultures of gauze swabs. A non-fiuorescent Pseudomonas, culturally distinguishable from the pseudomonas in the blood, was grown from the tap water.

The provincial bank began to supply blood to the hospital again a few days later, but the locally produced blood bottles were replaced by similar bottles prepared in the pharmacy of the university hospital. These had been sterilised by autoclaving with a plastic cover over the rubber membrane, and the latter was not disinfected. Whenever possible, blood was used within 3 days of collection, but during the summer months this limit was extended.

On 17 Aug. 1972, a febrile reaction occurred in another patient who had received a transfusion, and the same two organisms were grown from the remainder of the blood in the bottle (E. agglomerans $10^{8}$ per $\mathrm{ml}$, and $P$. fluorescens $5 \times 10^{7}$ per $\mathrm{ml}$ ). This patient also recovered.

A second investigation was carried out at the blood bank on 19 Aug. 1972. No growth was obtained from the blood in 56 bottles, and eight swabs from the interior of the refrigerator failed to yield either of the organisms found in the infected blood. On this occasion the acid-citrate-dextrose solution used for filling the pilot tubes was also examined. No growth was obtained from an unopened bottle, but a bottle marked " 1 May 1972 " contained E. agglomerans $\left(2 \times 10^{7}\right.$ per $\left.\mathrm{ml}\right)$ and $P$. fluorescens $\left(2 \times 10^{6}\right.$ per $\left.\mathrm{ml}\right)$, and a bottle marked " 8 August 1972 " contained E. agglomerans $\left(9 \times 10^{6}\right.$ per $\left.\mathrm{ml}\right)$. Two filled but unused pilot tubes each contained $10^{7}$ per $\mathrm{ml}$ of $E$. agglomerans.

\section{The infecting organisms}

Each of the isolates identified as E. agglomerans had the following characters: facultatively anaerobic, non-pigmented, motile, Gram-negative rod; nitrate reduced to nitrite; catalase positive; Voges-Proskauer reaction positive; citrate used as a sole carbon source; malonate utilised, gelatin liquefied in 3 days; oxidase negative; indol not produced; urease negative; KCN sensitive; acid and gas in glucose, and acid in mannitol, glycerol, dulcitol, arabinose, xylose, rhamnose, maltose, trehalose, sucrose, lactose and salicin, but not in adonitol, sorbitol or inositol in 7 days. This organism appeared to be a non-pigmented strain of E. agglomerans conforming most closely with group G1 of Ewing and Fife, though symplasmata were not observed.

The isolates identified as $\boldsymbol{P}$. fluorescens were all aerobic, motile, Gram-negative rods and formed a green fluorescent pigment. They were catalase and oxidase positive, and used citrate as a sole carbon source. There was no growth at $42^{\circ} \mathrm{C}$ and nitrate was not reduced. In 7 days they oxidised glucose, mannitol, adonitol, glycerol, inositol, arabinose, xylose, rhamnose and trehalose but not dulcitol, maltose, sucrose, lactose and raffinose. The strain conforms with Jessen's description of the type 54 of $P$. fluorescens and differs from the organism responsible for the earlier Danish episode (Kristensen) in not oxidising sucrose.

Growth at various temperatures.-Neither organism grew sufficiently at $36^{\circ} \mathrm{C}$ to cause 
turbidity in 24 days; and at $21^{\circ}-23^{\circ} \mathrm{C}$ both organisms were virtually fully grown after 1 day. At $4^{\circ} \mathrm{C}$, turbidity began to appear between the 6 th and the 9 th day (the table).

\section{Discussion}

In the investigation of the first incident, the two strains isolated from the transfused blood were not found in the environment of the blood bank, but were present in one other bottle of blood. Thus it appeared that the organisms might have been present in the bottle before the blood was collected, or have been introduced into the bottle during the bleeding session. In the second incident, however, contamination of the bottles could be excluded because they had been prepared elsewhere. The pilot tubes were not considered in the first investigation, because they were filled after the blood bottle and their content was used only for compatibility tests. The second investigation revealed E. agglomerans in two unused

TABLE

Growth of Enterobacter agglomerans and Pseudomonas fuorescens at various temperatures

\begin{tabular}{|c|c|c|c|c|c|c|c|c|c|c|c|}
\hline \multirow{2}{*}{ Organism } & \multirow{2}{*}{ Temperature } & \multicolumn{10}{|c|}{ Log ID50 of organisms per $0.1 \mathrm{ml}$ on day* } \\
\hline & & 1 & 2 & 3 & 4 & 5 & 6 & 7 & 8 & 9 & 10 \\
\hline $\begin{array}{l}\text { Enterobacter } \\
\quad \text { agglomerans }\end{array}$ & $\begin{array}{c}4^{\circ} \mathrm{C} \\
21^{\circ}-23^{\circ} \\
36^{\circ}\end{array}$ & $\begin{array}{l}\leqq 4.5 \\
7.9 \\
\leqq 4.5\end{array}$ & $\begin{array}{l}\leqq 4.5 \\
7.9 \\
\leqq 4.5\end{array}$ & $\begin{array}{r}\leqq 4.5 \\
7.9 \\
\leqq 4.5\end{array}$ & $\begin{array}{r}\leqq 4.5 \\
7.9 \\
\leqq 4.5\end{array}$ & $\begin{array}{r}\leqq 4.5 \\
7.9 \\
\leqq 4.5\end{array}$ & $\begin{array}{r}\leqq 4.5 \\
7.9 \\
\leqq 4.5\end{array}$ & $\begin{array}{r}6 \cdot 1 \\
7.9 \\
\leqq 4 \cdot 5\end{array}$ & $\begin{array}{r}7.7 \\
7.9 \\
\leqq 4.5\end{array}$ & $\begin{array}{r}7.7 \\
7.9 \\
\leqq 4.5\end{array}$ & $\begin{array}{r}8.1 \\
7.9 \\
\leqq 4.5\end{array}$ \\
\hline $\begin{array}{l}\text { Pseudomonas } \\
\text { fluorescens }\end{array}$ & $\begin{array}{c}4^{\circ} \mathrm{C} \\
21^{\circ}-23^{\circ} \\
36^{\circ}\end{array}$ & $\begin{array}{r}\leqq 4.5 \\
6.9 \\
\leqq 4.5\end{array}$ & $\begin{array}{l}\leqq 4.5 \\
6.9 \\
\leqq 4.5\end{array}$ & $\begin{array}{l}\leqq 4 \cdot 5 \\
7 \cdot 1 \\
\leqq 4.5\end{array}$ & $\begin{array}{l}\leqq 4 \cdot 5 \\
7 \cdot 1 \\
\leqq 4 \cdot 5\end{array}$ & $\begin{array}{l}\leqq 4.5 \\
7 \cdot 1 \\
\leqq 4.5\end{array}$ & $\begin{array}{r}5 \cdot 5 \\
7 \cdot 1 \\
\leqq 4.5\end{array}$ & $\begin{array}{r}6.5 \\
7.1 \\
\leqq 4.5\end{array}$ & $\begin{array}{r}7 \cdot 9 \\
7 \cdot 1 \\
\leqq 4.5\end{array}$ & $\begin{array}{r}7 \cdot 9 \\
7 \cdot 1 \\
\leqq 4 \cdot 5\end{array}$ & $\begin{array}{r}7.9 \\
7 \cdot 1 \\
\leqq 4.5\end{array}$ \\
\hline
\end{tabular}

The titres were unchanged between the 10th and 24th days.

* After inoculation (day $1=$ incubation for 1 day); for experimental details see text.

pilot tubes collected from the blood bank on 19 Aug. 1972 and in the stock citrate solution dated 8 Aug. 1972. Another bottle of citrate solution dated 1 May 1972 yielded E. agglomerans and $\boldsymbol{P}$. fluorescens, and may have been the source from which the blood collected on 2 Aug. 1972 was contaminated. Questioning revealed that both bottles were in current use, and that it was the practice to use the same bottle on many occasions, returning it to the refrigerator in the meantime. It seemed likely that the bottle with the later date may have been contaminated from the one with the earlier date; if so, the absence of $P$. fuorescens from the latter indicates a transfer of less than $0.0005 \mu \mathrm{l}$ of fluid from one bottle to the other; high-grade asepsis, indeed, but insufficient in the circumstance.

Laboratory experiments showed that it was almost impossible to avoid contaminating the fingers heavily with $E$. agglomerans when removing the rubber bung from one of the infected pilot tubes. It must therefore be assumed that the hands of the operator became similarly contaminated during the bleeding session, and that the organism was occasionally introduced through the rubber diaphragm in the course of inserting or removing the cannula.

\section{SUMmary}

Two patients suffered febrile reactions after being transfused with bank blood simultaneously contaminated with Enterobacter agglomerans and Pseudomonas fluorescens. The probable source of these organisms was the acid-citrate-dextrose solution used in the pilot tubes. Stock bottles of this were opened repeatedly and stored in the refrigerator in the meantime.

\section{REFERENCES}

Borden, C., AND Hall, W. H. 1951. Fatal transfusion reactions from massive bacterial contamination of blood. New Engl. J. Med., 245, 760. 
Braude, A. I., Sanford, J. P., Bartlett, Jane E., and Mallery, O. T. 1952. Effects and clinical significance of bacterial contaminants in transfused blood. J. Lab. Clin. Med. $39,902$.

EwING, W. H., AND FIFE, M. A. 1971. Enterobacter agglomerans, parts II and III. (U.S. Department of Health, Education, and Welfare, Public Health Service) Atlanta, Georgia.

Hugh, R., AND Leifson, E. 1953. The taxonomic significance of fermentative versus oxidative metabolism of carbohydrates by various Gram negative bacteria. J. Bact., 66, 24.

JesSEN, O. 1965. Pseudomonas aeruginosa and other green fluorescent pseudomonads. Copenhagen, table 29, p. 150, and pp. 200-201.

Kristensen, M. 1960. Bakteriologi og Sterilisationsteknik, Copenhagen, p. 151.

LAUTROP, H. 1956. Gelatin liquefying Klebsiella strains (Bacterium oxytocum Flügge). Acta path. microbiol. scand., 39, 375.

LAUTROP, H. 1972. Personal communication.

LWOFF, A. 1969. Death and transfiguration of a problem. Bact. Rev., 33, 390.

Benyesh-Melnick, Mathmida, ANd Melnick, J. L. 1959. The use of in-vitro markers and monkey neurovirolence tests to follow genetic changes in attenuated Poliovirus multiplying in the human alimentary tract. Int. Conf. on Live Poliovirus vaccines, Washington, p. 179.

OLSEN, H. 1966. The importance of temperature for the growth of Flavobacterium meningosepticum. Acta path. microbiol. scand., 67, 291.

SiBONI, K. 1972. Unpublished observations. 